DOI https://doi.org/10.18551/rjoas.2021-02.16

\title{
PERFORMANCE OF DROUGHT TOLERANCE RICE VARIETIES IN DIFFERENT PLANT GEOMETRY AT SUNDARBAZAR, LAMJUNG
}

\author{
Lamichhane Anish $^{1}$, Kadariya Ishwari Prasad $^{2 *}$, Nikita Bhandari $^{1}$ \\ ${ }^{1}$ Department of Agronomy, Plant breeding and Agriculture Statistics, Institute of Agriculture \\ and Animal Science, Tribhuvan University, Sundarbazar, Lamjung, Nepal \\ ${ }^{2}$ Center for Biotechnology, Agriculture and Forestry University, Rampur, Chitwan, Nepal \\ *E-mail: ipkadariya@afu.edu.np
}

\begin{abstract}
A field experiment was conducted in Agronomy farm of Lamjung campus during rainy season 2016. The main objective of the study was to evaluate high yielding drought tolerant rice varieties in typical rainfed condition at appropriate plant geometry. The experimental design was two factors randomized complete block design with three replications. Factor $A$ denotes varieties (Sukkhadhan-2 and Sukkhadhan-5) while the Factor B denotes plant spacing $(15 \mathrm{~cm}$ $\times 20 \mathrm{~cm}, 20 \mathrm{~cm} \times 20 \mathrm{~cm}, 20 \mathrm{~cm} \times 25 \mathrm{~cm}, 25 \mathrm{~cm} \times 25 \mathrm{~cm})$. The statistical result on grain yield revealed that the Sukkhdhan-5 has maximum grain yield $\left(4.9 \mathrm{t} \mathrm{ha}^{-1}\right)$ with harvest index (39.4\%) compared to Sukkhadhan-2 $\left(4.2 \mathrm{t} \mathrm{ha}^{-1}\right)$. The tested spacing shows that maximum yield $\left(5.2 \mathrm{t} \mathrm{ha}^{-1}\right)$ was obtained from $15 \mathrm{~cm} \times 20 \mathrm{~cm}$, while the lowest yield was at $25 \mathrm{~cm} \times$ $25 \mathrm{~cm}$ spacing. The highest grain yield in $15 \mathrm{~cm} \times 20 \mathrm{~cm}$ was due to higher effective tiller per hills, grains per panicle, harvest index. The interaction between the spacing and varieties shows non-significant effects on all of the parameters. Therefore, between two tested varieties and four different plant geometries, Sukkhadhan -5 varieties showed superior effect at spacing $15 \mathrm{~cm} \times 20 \mathrm{~cm}$ compared to other varieties and spacing. However, the results need to be confirmed on other varieties in different plant geometry used by farmers in the region.
\end{abstract}

\section{KEY WORDS}

Biological yield, drought, harvest index, plant spacing, yield attributes.

Rice (Oryza sativa L.), $2 n=2 x=24$, a member of Poaceae is among the three most important grain crops in the world, and it has a significant contribution to fulfill the food needs across the globe. The role of the rice crop is inevitable in the current and future global food security (Dhakal et al., 2020a). Rice is the most important staple food crop and ranks $1^{\text {st }}$ as most cultivated cereal crop in terms of both area and production in Nepal (Pokhrel et al., 2020; Dhakal et al., 2020b). Rice is grown in most parts of Nepal and grown on diversified environmental condition i.e., 60-3050 MASL (Sharma et al., 2020).

Numerous empirical studies suggest that climate change will have a bigger impact on agriculture in developing countries relative to developed countries (Stern 2006). However, the degree of the impact will depend upon the magnitude of the climate change and other factors. Increasing temperature will likely directly impact crops by affecting their physiology; it will also indirectly affect crops through changes in the water regime and the increased intensity of pests and diseases (Rosenzweig, 2000; Bale et al., 2002). Crops are also bound to be affected by more intense rainfall and other extreme weather events occurring at different stages of production. Projections on a likely increase in area-averaged seasonal surface air temperature and a change in area-averaged seasonal precipitation (with respect to the baseline period from 1961 to 1990) suggest a significant acceleration in warming in South Asia over what is observed for the $20^{\text {th }}$ century (Christensen et al., 2007). The warming, moreover, is projected to be stronger in the Himalayan Highlands including the Tibetan Plateau and the arid regions of Asia (Gao et al., 2003). Studies further project an increase in the inter-annual variability of daily precipitation in the Asian summer monsoon (Giorgi and $\mathrm{Bi}, 2005$ ). There has already been an increase in the frequency and intensity of rainfall events in many parts of Asia, which largely attributed to increasing temperature. This has caused severe floods, landslides and mud flows, while the number of rainy days and the 
total annual amount of precipitation has decreased in some regions (Lal, 2003; Min et al., 2003; Gruza and Rankova, 2004; Zhai, 2004). The frequency and intensity of droughts seem to have increased, particularly during the summer and the normally drier months (Gruza and Rankova, 2004; Natsagdorj et al., 2005). There is also concern that the glacier melt in the Himalayan region will increase flooding and affect water resources within the next two to three decades, which would inevitably be followed by decreased river flows as the glaciers recede. The warmer climate is also expected to lead to a higher intensity of extreme weather events increasing the risk of flash floods in parts of Nepal.

Drought is the major limiting factor regarding the loss of $20-30 \%$ of yield loss. For overcoming this there is need for the development of drought tolerant rice variety which can withstand on low moisture regime and gives better yield (Adhikari et al., 2015). Plant geometry is an important factor for rice production. It ensures plant to grow properly both in their aerial and underground parts through different utilization of solar radiation and nutrients. The optimum plant density depends on different factors that most importance of this factors includes plant characteristics, growth period duration, planting time and methods, soil fertility, plant situation of weeds. The objective of this study is to evaluate the performance of two drought tolerant rice varieties in different plant geometry and to find out the optimum plant geometry for getting better yield.

\section{MATERIALS AND METHODS OF RESEARCH}

The research was carried out at the Agronomy Farm of Institute of Agriculture and Animal Science, Sundarbazar, Lamjung at the altitude of $640 \mathrm{~m}$ asl with longitude of $84^{\circ} 11^{\prime}$ $-84^{\circ} 38^{\prime} \mathrm{E}$ and latitude of $28^{\circ} 3^{\prime}-28^{\circ} 30^{\prime} \mathrm{N}$ during the rainy season of 2016 . The soil of the experimental site was silty clay. It was fertile well drained and slightly acidic with $\mathrm{pH}$ varying from 6.68 to 6.92. The experiment was carried out in two factorial Randomization Complete Design (RCBD) with three replications and eight treatments. The treatment contains two different variety (Sukkhadhan-2 \& 5) as a Factor A and Four different spacing as a Factor B. The recommended dose of chemical fertilizer i.e. Urea (46\%), DAP $\left(18 \% \mathrm{~N}\right.$ and $\left.46 \% \mathrm{P}_{2} \mathrm{O}_{5}\right)$ and MOP $\left(60 \% \mathrm{~K}_{2} \mathrm{O}\right) @ 60: 30: 40$ for a rainfed condition was applied on the experimental plot. Organic manures are not applied on the experimental plot. Urea was applied as a top dressing at 22 DAT and 44 DAT, respectively. The nursey bed with plot size $1.5 \mathrm{~m} \times 1.5 \mathrm{~m}$ was prepared on $21^{\text {st }}$ of June. Uprooting of 30 days old seedling were carried out just before the transplanting day. The experimental field was flooded by using irrigation canal to facilitate puddling and transplanting. Water level was maintained $3-4 \mathrm{~cm}$ for 10 days and it was increased up to $10 \mathrm{~cm}$. Transplanting of rice was carried after the completion of layout operation on $21^{\text {st }}$ of July 2016. Hand transplanting was done for 30 days old seedling using 2-3 seedling per hill in each plant geometry. Manual weeding was carried out for weed management at 22 DAT and 44 DAT. Chemical control was not carried out. Rice Hispa (Dicladispa armigera) infestations was seen and it was above the threshold level. So, Cypermethrin @ 3ml per liter of water was applied on $17^{\text {th }}$ of August.

Harvesting was done separately for two variety because Sukkhadhan-2 has early maturity days compare to Sukkhadhan-5. Harvesting of Sukkhadha-2 was done on $24^{\text {th }}$ of October and harvesting of sukkhadha-5 was carried out on $10^{\text {th }}$ of November in 2016. Manual harvesting was carried out when the $50 \%$ of plant turned yellow. The boarder crop was harvested separately, and gross plot was harvested separately. The crop was left on the field 2 days for sun drying and biological yield was taken before threshing operation was employed. Harvested grain was cleaned by winnowing and paddle thresher was used for threshing operation. Grain weight and Straw weight was taken by using electrical balance and moisture content of grain was determined by using portable moisture meter. Two separate threshing operations was carried out for sukkhadhan-2 and sukkhadhan-5. After collecting and recording the penological observation, biometric observation and yield and yielding attributes were tabulated according to replication and treatments. Data entry and tabulation was finalized by using MS excel and for word processing Microsoft word 2016 was used. For assessing the statistical analysis, Microsoft computer program MSTAT-C was 
used. Analysis of variance and DMRT mean separation was computed. ANOVA table was used to test the significance of difference for each parameter. To find out the range between tested treatments Duncan's multiple Range test (DMRT) was used and test was done at $5 \%$ level of significance.

Table 1 - Different Factors used in this experiment

\begin{tabular}{|l|l|}
\hline S. N & Factors \\
\hline & Factor A (Variety) \\
\hline 1. & Sukkhadhan-2 \\
\hline 2. & Sukkhadhan-5 \\
\hline & Factor B (Spacing) \\
\hline 1. & $15 \mathrm{~cm} \times 20 \mathrm{~cm}$ \\
\hline 2. & $20 \mathrm{~cm} \times 20 \mathrm{~cm}$ \\
\hline 3. & $20 \mathrm{~cm} \times 25 \mathrm{~cm}$ \\
\hline 4. & $25 \mathrm{~cm} \times 25 \mathrm{~cm}$ \\
\hline
\end{tabular}

Table 2 - Treatment combination of varieties and spacing used in experiment

\begin{tabular}{|l|l|}
\hline Treatment & Treatment combination \\
\hline$T_{1}$ & Sukha-2 $+(15 \times 20 \mathrm{~cm})$ \\
\hline$T_{2}$ & Sukha-2 $+(20 \times 20 \mathrm{~cm})$ \\
\hline$T_{3}$ & Sukha-2 $+(20 \times 25 \mathrm{~cm})$ \\
\hline$T_{4}$ & Sukha- $+(25 \times 25 \mathrm{~cm})$ \\
\hline$T_{5}$ & Sukha- $5+(15 \times 20 \mathrm{~cm})$ \\
\hline$T_{6}$ & Sukha- $5+(20 \times 20 \mathrm{~cm})$ \\
\hline$T_{7}$ & Sukha- $5+(20 \times 25 \mathrm{~cm})$ \\
\hline$T_{8}$ & Sukha- $5+(25 \times 25 \mathrm{~cm})$ \\
\hline
\end{tabular}

\section{RESULTS AND DISCUSSION}

The statistical analysis revealed that $50 \%$ heading showed significant difference with the variety. Heading days was found early in Sukkhadhan-2 (91 days) while in 99 days $50 \%$ heading was observed in Sukkhadhan-5. 50\% heading days showed non-significant relationship with plant geometry. But regarding the statistical analysis $20 \mathrm{~cm} \times 20 \mathrm{~cm}$ showed slightly late heading days i.e., 96 days. However, the interaction between varieties and spacing showed non-significant relation to $50 \%$ heading days. Short heading varieties were preferred over long heading days varieties by farmers to increase the cropping intensity.

Statistically, maturity days shows significant relationship with variety. Sukkhadhan-2 has early maturity days (120 days) compared to Sukkhadhan-5 (130 days). Farmer preferred short days varieties i.e. Sukkhadhan-2 which has early maturity days. Regarding the result revealed both spacing and their interaction with varieties shows non-significant relationship to maturity days. All the varieties were found to be matured in 125 days in case of plant geometry.

Statistically non-significant differences were found between varieties and effects on different plant spacing. The highest plant height was measured in Sukhadhan-2 $(97 \mathrm{~cm})$ while only $92 \mathrm{~cm}$ was in Sukhadhan-5 variety. Regarding to the effect of different plant spacing on plant height, which was ranged from 91 to $99 \mathrm{~cm}$. The highest height was measured in $15 \mathrm{~cm}$ $x 20 \mathrm{~cm}$ while lowest height was in case of $25 \mathrm{~cm} \times 25 \mathrm{~cm}$. The less plant height in case of $25 \mathrm{~cm} \times 25 \mathrm{~cm}$ might be due to less competition of crop plants on solar radiation due to wide spacing compared to lower spacing. Similar result was observed i.e., lower spacing has longest plant height due to shedding effect (Thiyagarajan et al., 2002). Plant height is mainly governed by genetic buildup of plant with respect to environment and management aspects such as nutrient uptake, seedling vigor, etc.

Statistical data revealed showed that varieties have significant relationship with flag leaf area i.e., Sukkhadhan-5 have highest flag leaf area $\left(32.59 \mathrm{~cm}^{2}\right)$ and $29.11 \mathrm{~cm}^{2}$ was observed in case of Sukkhadhan-2. However, plant spacing and their interaction with varieties showed non-significant relationship with flag leaf area. 
Statistically non-significance differences found on panicle length in two tested varieties in the experiment and non-significance differences among tested spacings. But from the above table longest panicle was measured in Sukhadhan-5 $(21.3 \mathrm{~cm})$ while only $20.9 \mathrm{~cm}$ was in case of Sukhadhan-2. It may be a reason of producing highest grain yield of Sukhadhan-5 (4.9 t/ha) compared to Sukhadhan-2 (4.2 t/ha). Regarding to spacing, the longest panicle $(21.4 \mathrm{~cm})$ was measured in $20 \mathrm{~cm} \times 20 \mathrm{~cm}$ while lowest panicle length $(20.57 \mathrm{~cm})$ was measured in $25 \mathrm{~cm}, \times 25 \mathrm{~cm}$ spacing. It might be due to weed intensification so that plant must compete nutrients, water etc.

Statistically significance differences found between two tested varieties in the experiment. Higher number of effective tillers found in Sukhadhan-5 (218 tillers) while lower number in Sukhadhan-2 (192 tillers). Highest grain yield was obtained from Sukhadhan-5 may be due to a greater number of effective tillers per unit area compared to Sukhadhan-2. Similarly, in case of spacing, significance differences were not found among different spacing. Highest number of effective tillers was found in narrow spacing $(15 \times 20 \mathrm{~cm})$ followed by $20 \mathrm{~cm} \times 20 \mathrm{~cm}$. The greater number of tillers per unit area may be due to narrow spacing which increase plant density. Similar result was observed by (A. W. Baloch et al., 2002) i.e., wider space causes the individual plants to produce more tiller number but the hills number decreases reducing the final grain yield.

Filled grains per panicle are the most important yield attributing character, which determine the final grain yields. Statistically non-significant differences were found in different two varieties. The higher number of filled grains per panicle was observed in Sukhadhan-5 variety (117 grains) while lower filled grains were in Sukhadhan-2 (116 grains). Regarding to the effect of spacing on filled grains per panicle, the highest number of filled grains per panicle was found in $15 \mathrm{~cm} \times 20 \mathrm{~cm}$ and $20 \times 20 \mathrm{~cm}$ (120 grains each). Statistically the filled grains number in $15 \times 20 \mathrm{~cm}$ and $20 \times 20 \mathrm{~cm}$ were at par. Lower filled grains are found in higher spacing it might be due to higher the spacing more will be the weed infestation rate. Similar result i.e. narrow crop spacing with uniform plant distribution allows the crop plants to utilize limited available growth resources such as light, nutrients, and space more efficiently over weeds (Ashraf et al., 2014).

The statistical data reveled showed that unfilled grains per panicle had non-significant relationship with variety and interaction between plant geometry and variety but showed significant relationship with plant geometry. By regarding plant geometry, $25 \mathrm{~cm} \times 25 \mathrm{~cm}$ showed higher unfilled grains with $20 \mathrm{~cm} \times 25 \mathrm{~cm}$ at statistically par compared to $15 \mathrm{~cm} \times 20$ $\mathrm{cm}$ and $20 \mathrm{~cm} \times 20 \mathrm{~cm}$ which were statistically at par. The main reason behind higher unfilled grain is due to higher spacing have lower competition with crop but weeds biomass. Higher spacing ensure higher weed biomass and weed competes for nitrogen uptake which affects net photosynthetic rate and as a result husked grain are developed due to nutrient competition between crop and weeds (Hossain et al., 2002).

It refers to the ratio of unfilled grains to the total number of grains. The data reveled showed that non- significant relationship with varieties and their interaction with plant geometry. But in case of spacing higher sterility is shown by $25 \mathrm{~cm} \times 25 \mathrm{~cm}$ and lower by $15 \mathrm{~cm} \times 20 \mathrm{~cm}$. Statistically, it is at par with $20 \mathrm{~cm} \times 20 \mathrm{~cm}$. Lesser sterility rate is due to lesser husked grains. Similar result was shown by (Safdar et al. 2011). Optimum planting density $20 \mathrm{~cm} \times 20 \mathrm{~cm}$ provide minimum weed biomass then $25 \mathrm{~cm} \times 25 \mathrm{~cm}$ and have lesser husked grains and high grain yields

The grain yield was found significant with both variety and plant geometry. However, their interaction found to have non-significant relationship with grain yield. Sukkhadhan-5 has higher yield i.e. 4.9 ton per ha and Sukkhadhan-2 have 4.2 ton per ha. It is due to Sukkhadhan-5 was more adoptive to water stress and gives maximum tillering. Regarding plant geometry, $15 \mathrm{~cm} \times 20 \mathrm{~cm}$ have 5.2 ton per ha yield and $25 \mathrm{~cm} \times 25 \mathrm{~cm}$ have lower yield than other plant geometry. The main reason behind it was the low optimum plant population at higher spacing. Higher the planting distance the lower will be plant population and affects number of panicle and effective tiller per $\mathrm{m}^{2}$ and lesser filled grains due to sensitive to weed intensification. Similar result was observed by yield (Baloch et al., 2002; Vijayakumar et al., 
2004; Gozubenli., 2010; Kandil et al., 2010) i.e. wider space causes the individual plants to produce more tiller number but the hills number decreases reducing the final grain yield

The data revealed for biological yield showed significant with both variety and plant geometry. Biological yield obtained higher in case of Sukkhadhan-5 $\left(12.2 \mathrm{t} \mathrm{ha}^{-1}\right)$ than $10.7 \mathrm{t}$ ha $^{-1}$ yield of Sukkhadhan-2. Similarly, the effect of different spacing on biological yield showed that the maximum biological yield was measured in $(15 \times 20 \mathrm{~cm})(12.4 \mathrm{t} \mathrm{ha}-1)$ followed by wider spacing treatment $(20 \mathrm{~cm} \times 20 \mathrm{~cm})(11.7 \mathrm{t}$ ha-1) whereas minimum biological yield was obtained in $25 \times 25 \mathrm{~cm}$ spacing $(10.3 \mathrm{t}$ ha-1). The maximum biological yield in closer spacing $(15 \mathrm{~cm} \times 20 \mathrm{~cm})$ and $20 \mathrm{~cm} \times 20 \mathrm{~cm}$ might be due to high number of tillers per unit area and effective grains per unit area.

Straw yield is most important by product of rice for Nepalese farmers and it is used to feed livestock. Farmers have given second priority for straw yield during selection of rice varieties in their farm after rice grain yield. Statistically significant differences observed on straw yield in two varieties and non-significance differences on four spacings. Between two varieties, maximum straw yield was obtained in case of Sukhadhan-5 variety (7.35 tons ha-1) and slightly lower yield was obtained in Sukhadhan-2 (6.5 tons ha-1). Statistically nonsignificant differences observed on straw yield in different spacing. The maximum straw yield (7.15 t ha-1) was measured in closer spacing $(15 \mathrm{~cm} \times 20 \mathrm{~cm})$ followed by $20 \mathrm{~cm} \times 25 \mathrm{~cm}$ spacing $(7.10 \mathrm{t}$ ha- 1$)$ while less straw yield was found in wider spacing $(25 \mathrm{~cm} \times 25 \mathrm{~cm})(6.31 \mathrm{t}$ ha-1). The maximum straw yield in closer spacing might be due to high number of tillers per unit area.

Table 3 - Effect of variety and spacing on phenological characters of rice during rainy season, 2016

\begin{tabular}{|l|l|l|}
\hline Treatment & $50 \%$ Heading days & Maturity days \\
\hline Factor A: Variety & & \\
\hline Sukkhadhan-2 & $91^{\mathrm{b}}$ & $120^{\mathrm{b}}$ \\
\hline Sukkhadhan-5 & $99^{\mathrm{a}}$ & $130^{\mathrm{b}}$ \\
\hline F Test (at 5\%) & ${ }^{*}$ & ${ }^{*}$ \\
\hline LSD & 2.82 & 0.35 \\
\hline Factor B: Spacing & & \\
\hline $15 \mathrm{~cm} \times 20 \mathrm{~cm}$ & 95 & 125 \\
\hline $20 \mathrm{~cm} \times 20 \mathrm{~cm}$ & 96 & 125 \\
\hline $20 \mathrm{~cm} \times 25 \mathrm{~cm}$ & 95 & 125 \\
\hline $25 \mathrm{~cm} \times 25 \mathrm{~cm}$ & 95 & 125 \\
\hline F test (at $5 \%)$ & $\mathrm{Ns}$ & $\mathrm{Ns}$ \\
\hline LSD & 1.42 & 1.84 \\
\hline CV\% & 1.16 & 0.87 \\
\hline Interaction (A $\times$ B) & $\mathrm{Ns}$ & $\mathrm{Ns}$ \\
\hline Grand mean & 95 & 125 \\
\hline
\end{tabular}

Means within column followed by the same letter(s) do not differ significantly at 5\% DMRT.

Table 4 - Effect of variety and spacing on growth character of rice during rainy season 2016

\begin{tabular}{|l|l|l|l|}
\hline Treatment & Plant height $(\mathrm{cm})$ & Flag leaf area $\left(\mathrm{cm}^{2}\right)$ & Panicle length $(\mathrm{cm})$ \\
\hline Factor A: Variety & & & \\
\hline Sukkhadhan-2 & $97^{\text {a }}$ & $29.11^{\text {a }}$ & 20.9 \\
\hline Sukkhadhan-5 & $92.2^{\text {D }}$ & $32.59^{D}$ & 21.3 \\
\hline F Test (at 5\%) & ${ }^{D}$ & ${ }^{*}$ & Ns \\
\hline LSD & 4.56 & 2.59 & 0.79 \\
\hline Factor B: Spacing & & & \\
\hline $15 \mathrm{~cm} \times 20 \mathrm{~cm}$ & 99.1 & 32.08 & 21.30 \\
\hline $20 \mathrm{~cm} \times 20 \mathrm{~cm}$ & 93.1 & 30.99 & 20.57 \\
\hline $20 \mathrm{~cm} \times 25 \mathrm{~cm}$ & 94.3 & 30.63 & 21.40 \\
\hline $25 \mathrm{~cm} \times 25 \mathrm{~cm}$ & 91.1 & 29.70 & 21.20 \\
\hline F test (at $5 \%)$ & $\mathrm{Ns}$ & $\mathrm{Ns}$ & $\mathrm{Ns}$ \\
\hline LSD & 6.45 & 3.67 & 1.12 \\
\hline CV\% & 5.3 & 9.60 & 4.30 \\
\hline Grand Mean & 94.6 & 30.85 & 21.10 \\
\hline
\end{tabular}

Means within column followed by the same letter(s) do not differ significantly at 5\% DMRT. 
Statistically significance differences found in harvest index in two varieties and nonsignificance differences among 4 spacings. The maximum harvest index was found in Sukhadhan-5 (39.4\%) while slightly lesser index value was found in Sukhadhan-2 (38.7\%), Similarly, in the case of effect of different spacing on harvest index, the maximum harvest index was found in $15 \mathrm{~cm} \times 20 \mathrm{~cm}$ spacing (41.97\%) followed by $20 \times 20 \mathrm{~cm}$ spacing $(38.8 \%)$ and $25 \mathrm{~cm} \times 25 \mathrm{~cm}$ (38.3\%) while minimum HI was found in $20 \mathrm{~cm} \times 25 \mathrm{~cm}$ spacing (37.3\%). The more $\mathrm{HI}$ in case of closer spacing might be due to high grain yield.

Statistically significance differences found in test weight between two varieties. Between two varieties more test weight was measured in Sukhadhan-5 (28.9 g) while slightly less test weight was in case of Sukhadhan-2 $(27.1 \mathrm{~g})$. Similarly, in case of effect of different spacing on taste weight, the maximum test weight was found in wider spacing plot $(25 \mathrm{~cm} x$ $25 \mathrm{~cm})(28.2 \mathrm{~g})$ followed by $20 \mathrm{~cm} \times 25 \mathrm{~cm}$ spacing $(28 \mathrm{~g})$. Most of the farmers preferred fine grain type varieties compared to coarse type due to good taste and good market value. These two varieties were medium coarse type varieties, which are high yielder.

Table 5 - Effect of variety and spacing on growth factors on rice during rainy season 2016

\begin{tabular}{|l|l|l|l|l|}
\hline Treatment & Effective tillers $/ \mathrm{m}^{2}$ & Filled grains per panicle & Unfilled grains Per panicle & Sterility \% \\
\hline Factor A: Variety & & & & \\
\hline Sukkhadhan-2 & $192^{\mathrm{b}}$ & 116 & 14.3 & 11.13 \\
\hline Sukkhadhan-5 & $218^{\mathrm{a}}$ & 117 & 14.7 & 11.46 \\
\hline F Test (at 5\%) & ${ }^{*}$ & $\mathrm{Ns}$ & $\mathrm{Ns}$ & $\mathrm{Ns}$ \\
\hline LSD & 15.07 & 2.06 & 0.29 & 0.26 \\
\hline Factor B: Spacing & & & & $10.72^{\mathrm{b}}$ \\
\hline $15 \mathrm{~cm} \times 20 \mathrm{~cm}$ & 218 & $120^{\mathrm{a}}$ & $14^{\mathrm{b}}$ & $11.07^{\mathrm{b}}$ \\
\hline $20 \mathrm{~cm} \times 20 \mathrm{~cm}$ & 211 & $120^{\mathrm{a}}$ & $14^{\mathrm{b}}$ & $11.46^{\mathrm{a}}$ \\
\hline $20 \mathrm{~cm} \times 25 \mathrm{~cm}$ & 200 & $113^{\mathrm{b}}$ & $15^{\mathrm{a}}$ & $11.96^{\mathrm{a}}$ \\
\hline $25 \mathrm{~cm} \times 25 \mathrm{~cm}$ & 190 & $113^{\mathrm{b}}$ & $15^{\mathrm{a}}$ & ${ }^{*}$ \\
\hline F test (at 5\%) & $\mathrm{Ns}$ & ${ }^{*}$ & 0.36 \\
\hline LSD & 0.62 & 5.73 & 4.4 & 5.7 \\
\hline CV\% & 11.4 & 5.46 & 116.5 & $11 . .301$ \\
\hline Grand Mean & 205 & 116 & 14.5 & \\
\hline
\end{tabular}

Means within column followed by the same letter(s) do not differ significantly at 5\% DMRT.

Table 6 - Effect of variety and spacing on yield and yield attributing characters on rice during rainy season 2016

\begin{tabular}{|c|c|c|c|c|c|}
\hline Treatment & $\begin{array}{l}\text { Grain yield } \\
\text { (tons/ ha) }\end{array}$ & Biological yield (tons/ ha) & Straw yield (tons/ ha) & Harvest index \% & Test weight. (gm) \\
\hline \multicolumn{6}{|l|}{ Factor A: Variety } \\
\hline Sukkhadhan-2 & $4.2^{b}$ & $10.7^{b}$ & $6.50^{b}$ & $38.7^{b}$ & $27.1^{b}$ \\
\hline Sukkhadhan-5 & $4.9^{a}$ & $12.2^{a}$ & $7.35^{\mathrm{a}}$ & $39.4^{a}$ & $28.9^{a}$ \\
\hline F Test (at 5\%) & $\star *$ & * & * & * & * \\
\hline LSD & 0.31 & 0.52 & 0.84 & 0.65 & 0.96 \\
\hline \multicolumn{6}{|l|}{ Factor B: Spacing } \\
\hline $15 \mathrm{~cm} \times 20 \mathrm{~cm}$ & $5.2^{\mathrm{a}}$ & 12.4 & 7.15 & 41.97 & 27.8 \\
\hline $20 \mathrm{~cm} \times 20 \mathrm{~cm}$ & $4.6^{a b}$ & 11.7 & 7.14 & 38.8 & 27.9 \\
\hline $20 \mathrm{~cm} \times 25 \mathrm{~cm}$ & $4.3^{\mathrm{bc}}$ & 11.4 & 7.12 & 37.3 & 28.0 \\
\hline $25 \mathrm{~cm} \times 25 \mathrm{~cm}$ & $3.98^{c}$ & 10.3 & 6.31 & 38.3 & 28.2 \\
\hline $\mathrm{F}$ test (at $5 \%$ ) & ** & Ns & Ns & Ns & Ns \\
\hline LSD & 0.45 & 2.15 & 1.22 & 4.77 & 1.2 \\
\hline CV\% & 8.1 & 11.13 & 14.2 & 7.23 & 2.55 \\
\hline Grand Mean & 4.5 & 11.4 & 6.9 & 39.1 & 27.96 \\
\hline
\end{tabular}

Means within column followed by the same letter(s) do not differ significantly at 5\% DMRT.

\section{CONCLUSION}

The experiment concluded that the Sukkhadhan- 5 has maximum grain yield $\left(4.9 \mathrm{t} \mathrm{ha}^{-1}\right)$ with harvest index (39.4\%) compared to Sukkhadhan-2 $\left(4.2 \mathrm{t} \mathrm{ha}^{-1}\right)$. The tested spacing shows that maximum yield $\left(5.2 \mathrm{t} \mathrm{ha}^{-1}\right)$ was obtained from closer spacing of $15 \mathrm{~cm} \times 20 \mathrm{~cm}$, while the lowest yield was at $25 \mathrm{~cm} \times 25 \mathrm{~cm}$ spacing. The highest grain yield in $15 \mathrm{~cm} \times 20 \mathrm{~cm}$ was due to higher effective tiller per hills, grains per panicle, harvest index. The interaction 
between the spacing and varieties shows non-significant effects on all of the parameters. Therefore, between two tested varieties and four different plant geometries, Sukkhadhan-5 varieties showed superior effect at spacing $15 \mathrm{~cm} \times 20 \mathrm{~cm}$ compared to other varieties and spacing. However, it is recommended to conduct the research for multiple years at different regions of the country.

\section{ACKNOWLEDGEMENTS}

Authors express their deepest gratitude to farmers of Duradanda, Lamjung for theirs valuable support during the research period.

\section{REFERENCES}

1. Adhikari, B. B., B. Mehera, and S. M. Haefele. "Selection of drought tolerant rice varieties for the western mid hills of Nepal." Journal of the Institute of Agriculture and Animal Science (2015): 195-206.

2. Ashraf, Umair, et al. "Planting geometry-induced alteration in weed infestation, growth and yield of puddled rice." Pak. J. Weed Sci. Res 20.1 (2014): 77-89.

3. Bale, Jeffery S., et al. "Herbivory in global climate change research: direct effects of rising temperature on insect herbivores." Global change biology 8.1 (2002): 1-16.

4. Baloch, A. W., et al. "Optimum plant density for high yield in rice (Oryza sativa L.)." Asian J. Plant Sci 1.1 (2002): 25-27.

5. Christensen, Jens Hesselbjerg, et al. "Regional climate projections. Chapter 11." (2007).

6. Dhakal, Anup, et al. "Multivariate Analysis of Phenotypic Diversity of Rice (Oryza sativa L.) Landraces from Lamjung and Tanahun Districts, Nepal." International Journal of Agronomy 2020 (2020).

7. Dhakal Anup, et al. "Variability and heritability estimate of 30 rice landraces of Lamjung and Tanahun Districts, Nepal." Indonesian Journal of Agricultural Science 21.1 (2020): 1-10.

8. Gao, X. J. "Climate changes due to green-house effects in Qinghai-Xizang Plateau and along Qianghai-Tibet Railway." Plateau Meteorol 22 (2003): 458-463.

9. Giorgi, Filippo, and Xunqiang Bi. "Regional changes in surface climate interannual variability for the 21st century from ensembles of global model simulations." Geophysical Research Letters 32.13 (2005).

10. Gözübenlı, H. "Influence of planting patterns and plant density on the performance of maize hybrids in the Eastern Mediterranean conditions." International Journal of Agriculture and Biology 12.4 (2010): 556-560.

11. Gruza, G. V., and E. Ya Rankova. "Detection of changes in climate state, climate variability, and climate extremity." Russian Meteorology and Hydrology 4 (2005): 31-43.

12. Kandil, A. A., et al. "Effect of hill spacing, nitrogen levels and harvest date on rice productivity and grain quality." Crop Environ 1.1 (2010): 22-26.

13. Lal, Murari. "Global climate change: India's monsoon and its variability." Journal of Environmental Studies and Policy 6.1 (2003): 1-34.

14. Min, Seung-Ki, et al. "Spatial and temporal comparisons of droughts over Korea with East Asia." International Journal of Climatology: A Journal of the Royal Meteorological Society 23.2 (2003): 223-233.

15. Natsagdorj, L., Gomboluudev, P., Batima, P. (2005). Climate change in Mongolia', in Batima, P; Myagmarjav, B (eds). Climate Change and its Projections, Ulaanbaatar: ADMON Publishing, pp. 39-84.

16. Batima, Punsalmaa, et al. "Observed climate change in Mongolia." Assess Imp Adapt Clim Change Work Pap 12 (2005): 1-26.

17. Pokhrel, Amrit, et al. "Evaluation of Physicochemical and Cooking Characteristics of Rice (Oryza sativa L.) Landraces of Lamjung and Tanahun Districts, Nepal." International journal of food science 2020 (2020). 
18. Rosenzweig, Cynthia, et al. "Climate change and extreme weather events-Implications for food production, plant diseases, and pests." (2001).

19. Sharma, S., et al. "Agro-morphological characterization of rice (Oryza sativa L.) landraces of Lamjung and Tanahun District, Nepal." Annals of Plant Sciences 9.2 (2020): 37313741.

20. Stern, Nicholas, and Nicholas Herbert Stern. The economics of climate change: the Stern review. cambridge University press, 2007.

21. Thiyagarajan, T. M., et al. "Crop management options for increasing water productivity in rice." Journal of agricultural resource management 1.4 (2002): 169-181.

22. Vijayakumar, M., et al. "Effect of SRI (System of Rice Intensification) practices on the yield attributes, yield and water productivity of rice (Oryza sativa L.)." Acta Agronomica Hungarica 52.4 (2005): 399-408. 